Kovalenko., V., Syniov, V., Peretiaha, L., \& Halii, A. (2021). The current state of involvement of children with special educational needs in out-of-school education in Ukraine. Amazonia Investiga, 10(42), 31-42. https://doi.org/10.34069/AI/2021.42.06.4

\title{
The current state of involvement of children with special educational needs in out-of-school education in Ukraine
}

\section{Сучасний стан залучення дітей з особливими освітніми потребами до позашкільної освіти в Україні}

\author{
Received: May 13, 2021
}

Accepted: May 18, 2021

\author{
Written by: \\ Kovalenko Viktoriia ${ }^{15}$ \\ https://orcid.org/0000-0002-7792-4653 \\ Syniov Viktor ${ }^{16}$ \\ https://orcid.org/0000-0001-8223-5919 \\ Peretiaha Liudmyla ${ }^{17}$ \\ https://orcid.org/0000-0002-3686-2601 \\ Halii Alla ${ }^{18}$ \\ https://orcid.org/0000-0002-2134-6321
}

\begin{abstract}
The paper considers the current state of involvement of children with special educational needs in out-of-school education. The purpose of the article is to study the qualitative composition of groups of children with special educational needs who are involved in out-of-school education based on the type of developmental disorder; forms of involvement; areas of out-of-school education in which children with special educational needs are studied; determining the impact of out-of-school education on the development and socialization of children with special educational needs. At the first stage, the state of the problem development in domestic science was studied; at the second stage - the author's questionnaire and expert evaluation procedures were developed; a statement experiment was conducted using the survey method and the method of expert assessments; at the third stage, the analysis, systematization, processing of the accumulated empirical material is conducted. It has been determined that children with musculoskeletal disorders, mental disorders, autism spectrum
\end{abstract}

\begin{abstract}
Анотація
У статті розглядається сучасний стан залучення дітей 3 особливими освітніми потребами до позашкільної освіти. Метою статті є вивчення якісного складу груп дітей 3 особливими освітніми потребами, які залучаються до позашкільної освіти за ознакою типу порушення розвитку; форм залучення; напрямів позашкільної освіти, за якими здійснюється навчання дітей 3 особливими освітніми потребами; визначення впливу позашкільної освіти на процеси розвитку та соціалізації дітей 3 особливими освітніми потребами. На першому етапі вивчався стан розробленості проблеми у вітчизняній науці; на другому етапі - здійснювалась розробка авторського опитувальника та процедури експертного оцінювання; проводився констатувальний експеримент із використанням опросного методу та методу експертних оцінок; на третьому етапі здійснюється аналіз, систематизація, обробка накопиченого емпіричного матеріалу. Встановлено, що до закладів позашкільної освіти залучаються
\end{abstract}

\footnotetext{
15 Candidate of Psychological Sciences (PhD), Doctoral Candidate of Faculty of Special and Inclusive Education, National Pedagogical Dragomanov University, Associate Professor of Faculty of Nature, H.S. Skovoroda Kharkiv National Pedagogical University, Ukraine.

${ }^{16}$ Doctor of Pedagogy, Professor of Education of Faculty of Special and Inclusive Education, National Pedagogical Dragomanov University, Ukraine.

${ }^{17}$ Doctor of Pedagogy, Professor of Education of Faculty of Nature, Head of the Department of Special Pedagogy, H. S. Skovoroda Kharkiv National Pedagogical University, Ukraine.

${ }^{18}$ Candidate of Biological Sciences, (PhD), Head of the Department of Human Health, Rehabilitology and Special Psychology, H.S. Skovoroda Kharkiv National Pedagogical University, Ukraine.
} 
disorders, mental retardation, severe speech disorders, hard of hearing, deafness, the visually impaired, and children with blindness are involved in out-of-school educational institutions. Children with special educational needs are involved in clubs (creative associations) of artistic and aesthetic, physical culture and sports, art, tourism and local lore, social rehabilitation, ecological and naturalistic, scientific and technical, health, humanitarian, research, and experimental and militarypatriotic areas of out-of-school education.

Keywords: children with special educational needs, schoolchildren with mental disabilities, out-of-school education, directions of out-ofschool education, socialization. діти 3 порушеннями опорно-рухового апарату, інтелектуальними порушеннями, розладами аутистичного спектру, із затримкою психічного розвитку, тяжкими порушеннями мовлення, слабочуючі, діти 3 глухотою, слабозорі та діти зі сліпотою. Діти 3 особливими освітніми потребами залучаються до гуртків (творчих об'єднань) художньо-естетичного, фізкультурноспортивного, мистецького, туристськокраєзнавчого, соціально-реабілітаційного, еколого-натуралістичного, науковотехнічного, оздоровчого, гуманітарного, дослідницько-експериментального та військово-патріотичного напрямів позашкільної освіти. Позитивний вплив залучення дітей до позашкільної освіти, на думку педагогів та експертів виявляється в сприянні їх соціалізації; соціальному, духовному, моральному розвитку; наданні можливостей дитині для самореалізації тощо.

Ключові слова: діти з особливими освітніми потребами, школярі 3 інтелектуальними порушеннями, позашкільна освіта, напрями позашкільної освіти, соціалізація.

\section{Introduction}

The modern system of out-of-school education in Ukraine is designed to promote the development of abilities and talents of children, to satisfy their interests and needs in professional determination. It is especially true for children with special educational needs because they characterized by complications of development and socialization, which negatively affects the degree of their social integration and occupational adaptation (Syniov et al., 2019). Note that in addition to educational and developmental activities, out-of-school educational institutions are actively implementing important social functions (Trani et al., 2019). In this regard, Nasyrova, Muller (2019) notes that out-of-school education is a chance to develop the abilities of children with special educational needs (visual, hearing, musculoskeletal, speech, autism spectrum disorders, mental disabilities) and the opportunity to acquire knowledge and skills that can be used for self-realization in professional activities.

According to the Ministerio de Educación y Ciencia de Ucrania (2021), out-of-school education covered 1 million 190 thousand children, including 9.5 thousand children with special educational needs. Children have the opportunity to attend clubs and creative associations of artistic and aesthetic, artistic, experimental, tourist and local lore, environmental and naturalistic, physical culture and sports, health, military and patriotic, library and bibliographic, social and rehabilitation, humanitarian areas of out-of-school education. Thus, in the 2019-2020 study year 73.7 thousand circles (creative associations, sections, studios) of various directions of out-of-school education functioned in out-of-school education institutions; among them, the largest number of children (44\%) was involved in artistic and aesthetic activity, the least number of children (1\%) was involved in health-improving. Simultaneously, the Minister of Ministerio de Educación y Ciencia de Ucrania (2021) S. Shkarlet, reporting at the Education Forum 2021, emphasized that in 2021 the number of outof-school education institutions decreased by 26 units (2021). However, there is a positive trend in increasing the number of children with special educational needs in these institutions. However, in most cases, the involvement of such children in out-of-school education occurs spontaneously, without understanding the specifics of their psychophysical development, their potential and needs, features of interests. Simultaneously, Pustovit (2013); Kamenez, Vaganova, Smirnova, Kutepova, \& Vinokurova (2019) points out that the involvement of children with special scientific and technical, research and 


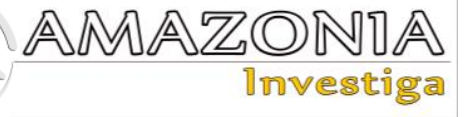

educational needs in out-of-school educational institutions should be aimed at improving their socialization and development, in terms of corrective targeted pedagogical influence through their inclusion in the accessible areas of cognitive, domestic, creative, and socialsignificant activities co0nsidering the individual interests and capabilities of children. Thus the following study is devoted to the analysis of modern scientific research on the problem of involving children with special educational needs in out-of-school education in Ukraine.

\section{Literature Review}

Some issues of involving children with special educational needs in out-of-school education institutions are reflected in the scientific works of domestic scientists (Litovchenko (2013), Omelyanovich (2015), Syniov (2018), Syniov \& Kovalenko (2021), Suprun, Vysotska \& Gladchenko (2014), Tatyanchikova (2016), Shulzhenko (2021) Out-of-school education is considered as an environment in which educational, developmental, orientationprofessional, correctional, creative, constructive and sports services for children with special educational needs should be provided; it is an environment where the child can find motivation to carry out own semantic, activity and personal needs, the satisfaction of which contributes to a good mood, harmonization of emotional states, overcoming aggressive behavior, self-control and self-regulation of their own actions, the formation of dialogue, communication, in particular, and verbal and alternative communication (Shulzhenko, 2021).

Litovchenko (2013) analyzed modern models of the involvement of children and youth with special needs in out-of-school education as a significant factor in their socialization. The leading models are the integration of children with special educational needs into groups of children with normative development (on the principle of inclusive education); creation on the basis of special institutions of separate circles; the creation of rehabilitation centers for out-ofschool education. Syniov et al. (2021) analyzed modern models of involving children with special educational needs in the educational process of out-of-school educational institutions and identified the following four models: "collective educational integration" in the form of group work conducted on the basis of a special educational institution.; "educational inclusion" in the form of inclusive education in a group of children with normative development; "combined model" for children with complex developmental disorders, which combine individual lessons with group work; "mass" model, which provides for involving children with special educational needs in concerts, competitions, exhibitions and performances.

Suprun et al. (2014) analyze the problems of socialization of people with mental disabilities. Scientists emphasize the importance of children activity in choosing certain types of leisure activities, and the importance of pupils' selfgovernment. Simultaneously, special education teachers face with the task of creating such methodological conditions under which the use of opportunities and educational resources of correctional and educational process in educational institutions would be the most effective.

Shields, King, Corbett \& Eames (2013) determine that children with mental disabilities rarely participate in out-of-school activities than their peers with normative development. Fatih, Ganera (2020) define that lower levels of participation in leisure activities, sports competitions for children with mental disabilities are associated with deteriorating health and social isolation.

Tatyanchikova (2016) reveals that "senior pupils with mental disabilities experience significant difficulties in organizing leisure, in choosing certain activities according to their preferences, abilities and inclinations." It highlights the problem of providing psychological and pedagogical assistance in ensuring that the child uses individual characteristics in spare time outside the special school.

Omelyanovich (2015) focuses on the unsatisfactory state of socialization of adolescent graduates with mental disabilities. The scientist points to the presence of a large number of young people with mental disabilities (about 40\%) who are not employed. $57 \%$ of graduates do not like the profession they receive at school. The researcher determines the need to find new ways to address the issue of vocational socialization of people with mental disabilities. Thus, the work is an important way of their rehabilitation, and various forms and types of employment of such people are considered a major factor in their successful integration into society. In this context, the involvement of people with special educational needs in out-of-school education is of particular importance because the aim is career guidance and helping each child to believe in their abilities and discover their potential. 
Simultaneously, the highlighted aspects do not give a holistic view of the state of involvement of children with special educational needs in out-ofschool education in Ukraine, do not provide a comprehensive approach that summarizes and systematizes the existing theoretical and practical potential to out-of-school education. In particular, the following issues remain unresolved:

- which groups of children with special educational needs (hearing, vision, speech, musculoskeletal disorders, mental disabilities, mental retardation, autism spectrum disorders) are involved in out-ofschool education;

- in what form children with special educational needs are involved in out-ofschool education; children with special educational needs are involved in creative associations of which areas of out-of-school education;

- whether they are provided with qualified (defectological) support;

- whether the current opportunities and needs of such children in the organization of outof-school education are considered and how they are considered;

- what is the positive impact of involving children with special educational needs in creative associations of out-of-school education.

First, we can talk about the high level of the current state of the problem of improving the level of socialization of children with special educational needs, which require justification of educational opportunities for out-of-school education, which are potential at this stage. Second, the condition of not only theoretical but also practical and social significance of the results of the study is the involvement of special education teachers in out-of-school education. It is necessary to justify the potential of out-ofschool education and, consequently, the development of appropriate scientific and methodological and organizational and pedagogical support.

\section{Methodology}

The study of the state of involvement of children with special educational needs in out-of-school education in Ukraine was conducted in several stages.
At the first stage - analytical and ascertaining the state of the problem of elaboration in domestic science was studied, psychological and pedagogical literature was analyzed, methodological approaches were determined.

At the second stage - analytical and exploratory the author's questionnaire was developed and the expert evaluation procedure was conducted; a stated experiment was conducted using the survey method and the method of expert evaluations.

At the third stage - generalizing - the analysis, systematization, processing of accumulated empirical material is conducted; theoretical generalization, interpretation, and design of research results are also conducted.

During the analytical and ascertaining stage the methodological basis of the research was determined as follows: the idea of the educational and socio-pedagogical potential of out-of-school education institutions (Bykovska (2016), Pustovit (2013)); personality-oriented concept of child development (Bekh (2018), Maksymenko et al. (2013)), provisions on the socialization of persons with psychophysical disorders (Khokhlina (2019), Shulzhenko (2021)).

The study investigated the current state of participation of children with special educational needs in out-of-school education on the following indicators:

- high-quality composition of groups of children with special educational needs who are involved in out-of-school education based on the type of developmental disorder;

- forms of involvement of children with special educational needs in out-of-school education;

- directions of out-of-school education in which children with special educational needs are studied;

- determining the impact of out-of-school education on the processes of development and socialization of children with special educational needs;

- identification of difficulties for teachers of out-of-school education institutions in the process of teaching children with special educational needs.

The author's questionnaire for teachers of out-ofschool education institutions was developed at the second stage. It was titled "Teachers about children with special educational needs in out-ofschool education." The questionnaire consists of 


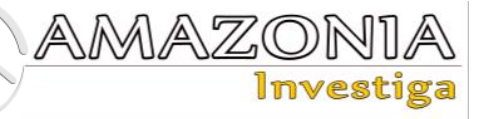

12 questions: 4 auxiliary questions and 8 main questions.

Auxiliary questions included open-ended and closed-ended questions, which had the main characteristics of the target audience and served as a basis for the main questions. The content of these questions is the following: 1. Personal data: last name, first name, patronymic name. 2. Teacher affiliation. 3. Job title. 4. Contact details.

The main questions follow: closed; closed with answer options; open. The content of these questions is following:

1. What categories of children with special educational needs study in your institution? (children with mental retardation; mental disabilities (irreversible); star blind, children with blindness; hearing-impaired children, children with deafness; with musculoskeletal disorders; with autism spectrum disorders; with severe speech disorders);

2. Which forms of involvement of children with special educational needs in the educational process are available in your institution? (inclusive education; collective educational integration; individual learning; your option);

3. In what areas of out-of-school education are children with special educational needs taught in your institution? (artistic-aesthetic; artistic; tourist-local history; ecologicalnaturalistic; scientific-technical; researchexperimental; physical culture-sports or sports; military-patriotic; librarybibliographic; social-rehabilitation; healthimproving; humanitarian).

4. What areas of out-of-school education involve children with mental disabilities of primary school age in your institution? (artistic and aesthetic; artistic; tourist and local lore; ecological and naturalistic; scientific and technical; research and experimental; physical culture and sports or sports; military and patriotic; library and bibliographic; social and rehabilitation; health; humanitarian).

5. What areas of out-of-school education involve children with mental disabilities in your institution? (artistic-aesthetic; artistic; tourist-local lore; ecological-naturalistic; scientific-technical; research-experimental; physical culture-sports or sports; militarypatriotic; library-bibliographic; socialrehabilitation; health-improving; humanitarian).

6. In what areas of out-of-school education are children with mental disabilities of senior school age involved in your institution? (artistic-aesthetic; artistic; tourist-local lore; ecological-naturalistic; scientific-technical; research-experimental; physical culturesports or sports; military-patriotic; librarybibliographic; social-rehabilitation; healthimproving; humanitarian)

7. What is the positive impact of involving children with special educational needs in out-of-school education on their development?

8. What difficulties do you have working with children with special educational needs? (insufficient knowledge of special methods of teaching children with special educational needs; no problems; lack of material and technical base; lack of cognitive interest in children; the presence of obvious behavioral disorders in children; difficulties in establishing productive contact and interaction with children with special educational needs; your option).

The survey of teachers of out-of-school educational institutions was conducted in the form of an online survey using Google Survey. One hundred thirty-two teachers of out-of-school education institutions from all regions of Ukraine took part in the study. After the survey, to increase the objectivity of the interpretation of the experimental data, each respondent was additionally interviewed individually using Google Meet.

The method of expert evaluation was also used during the experimental study to determine the impact of out-of-school education on the development and socialization of children with special educational needs. It is used to justify that the role of expert methods acquires special significance in the period of lack of theoretical and experimental information on the use of outof-school education resources in the development and socialization of children with special educational needs. It is also used to determine the optimal psychological and pedagogical conditions for their involvement in out-of-school education. In such circumstances, there is a high degree of uncertainty about the influence of factors of stay of children with special educational needs in out-of-school educational institutions on the processes of their development and socialization, and therefore acceptable accuracy of results cannot be ensured by any statistical or other formalized methods (Novosad et al., 2009). Because the most difficult group to engage in out-of-school education are 
children with mental disabilities, who have significant complications in development and socialization and require modification of programs in all areas of out-of-school education (Syniov et al., 2021), most of the questions addressed to the experts concerned this group of children. Therefore, the experts were asked modified 4-7 questions of the questionnaire:

Do you think that it is most useful for children of primary school age with mental disabilities to attend classes in which areas of out-of-school education? (artistic-aesthetic; artistic; touristlocal history; ecological-naturalistic; scientifictechnical; research-experimental; physical culture-sports or sports; military-patriotic; library-bibliographic; social-rehabilitation; health-improving; humanitarian)?

Do you think that it is most useful for adolescents with mental disabilities to attend classes in which areas of out-of-school education? (artisticaesthetic; artistic; tourist-local history; ecological-naturalistic; scientific-technical; research-experimental; physical culture-sports or sports; military-patriotic; library-bibliographic; social-rehabilitation; health-improving; humanitarian)?

Do you think that it is most useful for high school children with mental disabilities to attend classes in which areas of out-of-school education? (artistic-aesthetic; artistic; tourist-local history; ecological-naturalistic; scientific-technical; research-experimental; physical culture-sports or sports; military-patriotic; library-bibliographic; social-rehabilitation; health-improving; humanitarian)?

What is the positive impact of involving children with special educational needs in out-of-school education on their development?

Leading defectologists, doctors of sciences, and professors acted like experts. The category of experts included research and teaching staff of The National Pedagogical Dragomanov University; Donbass State Pedagogical University; Ivan Franko National University of Lviv; Kherson State University; H. S. Skovoroda Kharkiv National Pedagogical University. Sixtythree experts took part in the study.

\section{Results and Discussion}

The results of a survey of teachers on the method of "Teachers of children with special educational needs in out-of-school education" should be considered in more detail. Thus, answering the question: "What categories of children with special educational needs study in your institution?" 293 answers were received (questions with multiple choice). It was found that among all groups of children with special educational needs who attend out-of-school education, the majority are children with musculoskeletal disorders (16.72\%), mental disabilities (16.38\%), and autism spectrum disorders $(15.36 \%)$. Children with mental retardation $(13.99 \%)$, severe speech disorders $(10.24 \%)$, hard of hearing $(9.56 \%)$, children with deafness $(8.87 \%)$ are also involved in out-ofschool education. The smallest number of children involved in out-of-school education are visually impaired children $(7.17 \%)$ and children with blindness (1.17). It can be explained that most educational programs of out-of-school education are focused on children, creating a specific product of their activities, and working with children with visual impairments requires teachers to have alternative communication tools, including Braille. In most cases, such skills are absent from teachers of out-of-school educational institutions, as indicated by our results. In particular, it was found that $19.63 \%$ of teachers among the typical difficulties in attracting children with special educational needs highlight "insufficient knowledge of special methods and technologies of teaching such children."

The question "What forms of involvement of children with special educational needs in the educational process is available in your institution?" (multiple answer: inclusive learning; collective educational integration; individual learning; your version) received 159 answers. It is determined that the leading model of involvement of children with special educational needs in out-of-school education institutions is collective educational integration $(50.94 \%)$, i.e. a group of children of one nosological group (up to 10 people) attends a circle on the basis of out-of-school education institution. schools. Teachers noted that this form is optimal for children because they have modalspecific patterns of development due to primary developmental disorders, all simultaneously study a modified (simplified) program of a particular area of out-of-school education. In such conditions it is easier to create a situation of "success" for each child, which is critical to maintain the interest of the child in the classroom. This opinion of teachers confirmed by Shulzhenko (2021), who notes that a sign of outof-school education is a positive emotional atmosphere in a group of children, tolerance, equality and success of everyone. Every child 


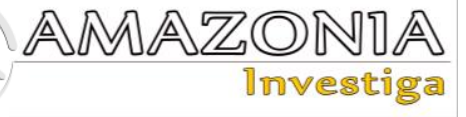

with special educational needs can feel significant and successful under the conditions of creating psychological conditions based on the principles of special didactics. The existence of inclusive education of children in out-of-school education institutions as evidenced by $20.75 \%$ of teachers' answers (inclusion of 1-3 children with special educational needs in the group of children with normative development); $28.31 \%$ of teachers' answers indicated individual education in an out-of-school education institution. Simultaneously, during clarifying conversations, teachers pointed out that in most cases they try combining individual learning with the involvement of children with special educational needs in group work (collective), but in the presence of clear developmental disorders (blindness, severe mental disabilities, movement apparatus) leading are only individual training.

Answering multiple-choice questions "What areas of out-of-school education are taught to children with special educational needs in your institution?" 325 responses were received. It is determined that most parents and children with special educational needs choose and attend

clubs (creative associations) of artistic and aesthetic $(28.62 \%)$, physical culture and sports $(15.08 \%)$, or art areas of out-of-school education (13.84\%). $8.62 \%$ of children with special educational needs are involved in clubs or creative associations in the field of tourism and local lore, $8.62 \%$ in social and rehabilitation, $7.08 \%$ in ecological and naturalistic, $6.46 \%$ in scientific and technical, and health-improving. $5.54 \%$, humanitarian $-4.61 \%$, research and experimental $-1.23 \%$, military-patriotic $-0.3 \%$. No child with special educational needs attends the library and bibliographic circle. These results indicate a similar trend in the choice of leisure activities (areas of out-of-school education) by children with normative development and special educational needs (Ministerio de Educación y Ciencia de Ucrania, 2021). In particular, both groups of children are involved in circles of artaesthetic and physical culture-sports directions of out-of-school education.

The study analyzed the areas of out-of-school education attended by children with mental disabilities of primary school, adolescence, and senior school age. See Table 1.

Table 1.

Involvement of school-age children with mental disabilities in the areas of out-of-school education.

\begin{tabular}{|c|c|c|c|}
\hline \multirow[b]{2}{*}{ Areas of out-of-school education } & \multicolumn{3}{|c|}{$\begin{array}{l}\text { Involvement of children with mental disabilities (average percentage of the } \\
\text { indicator) }\end{array}$} \\
\hline & $\begin{array}{l}\text { primary school } \\
\text { children (sample is } \\
410 \text { ) }\end{array}$ & $\begin{array}{l}\text { teenagers (sample is } \\
278 \text { ) }\end{array}$ & $\begin{array}{l}\text { senior pupils (sample } \\
\text { is } 393 \text { ) }\end{array}$ \\
\hline Art and aesthetics & 29.27 & 22.30 & 20.11 \\
\hline Art & 7.07 & 18.35 & 16.79 \\
\hline Tourist and local lore & 23.66 & 12.95 & 13.49 \\
\hline Ecological and naturalistic & 11.95 & 14.03 & 12.72 \\
\hline Scientific and technical & 5.38 & 7.91 & 8.91 \\
\hline Research and experimental & 4.14 & 6.83 & 9.92 \\
\hline Physical culture or sports & 18.29 & 17.63 & 15.52 \\
\hline Military and patriotic & 0 & 0 & 0 \\
\hline Library and bibliographic & 0 & 0 & 0 \\
\hline Social rehabilitation & 0.24 & 0 & 2.54 \\
\hline Wellness & 0 & 0 & 0 \\
\hline Humanitarian & 0 & 0 & 0 \\
\hline
\end{tabular}

The table shows that most primary school children are involved in art and aesthetics (29.27\%), physical culture or sports $(18.29 \%)$, tourism and local lore $(23.66 \%)$, ecological and naturalistic $(11.95 \%)$. Fields of out-of-school education. Children are involved in art $(7.07 \%)$, scientific and technical $(5.38 \%)$, research and experimental $(4.14 \%)$, and social rehabilitation $(0.24 \%)$ fields of out-of-school education. Simultaneously, it has been determined that children with mental disabilities are not involved in military-patriotic, library-bibliographic, health-improving, and humanitarian fields of out-of-school education.

Among teenagers with mental disabilities, the most popular are art and aesthetic $(22.30 \%)$ and art $(18.35 \%)$ fields of out-of-school education. The teenagers with mental disabilities are rarely involved in physical culture or sports $(17.63 \%)$, ecological and naturalistic (14.03\%), tourism and local lore $(12.95 \%)$, scientific and technical $(7.91 \%)$, and research and experimental $(6.83 \%)$ fields of out-of-school education. Teenagers with mental disabilities who attend military-patriotic, 
library-bibliographic, social-rehabilitation, health-improving, and humanitarian fields of out-of-school education have not been identified.

Analyzing the involvement of senior pupils with mental disabilities in various areas of out-ofschool education, it was found that most children are involved in art and aesthetic circles $(20.11 \%)$, art $(16.79 \%)$, and sports $(15.52 \%)$ fields of outof-school education. Senior pupils rare are involved in tourism and local lore (13.49\%), ecological and naturalistic $(12.72 \%)$, research and experimental (9.92\%), scientific and technical $(8.91 \%)$, and social rehabilitation $(2.54 \%)$ fields of out-of-school education. No senior pupils with mental disabilities attending clubs or other creative associations of militarypatriotic, library-bibliographic, healthimproving, and humanitarian fields of out-ofschool education were found.

Also, primary school children are rarely involved in out-of-school education than teenagers and senior pupils. It indicated by the number of choices by teachers of out-of-school education institutions $(410 ; 278 ; 393)$.

The study analyzed the impact of involving children with special educational needs in out-ofschool education on their development. The results of the survey of teachers of out-of-school educational institutions indicate that the positive impact on children is evidenced in the optimization of the process of assimilation and internalization of cultural elements, the overall development of the child $(34.46 \%)$; social, spiritual, moral development, providing opportunities for the child for self-realization (16.89\%); development of communication and social skills $(13.51 \%)$, improvement of social adaptation and integration of these children (4.73\%); personal development $(6.76 \%)$; preparation for life in society, the formation of life goals $(5.41 \%)$; correction of existing developmental disorders $(4.73 \%)$; creative development $(3.38 \%)$; harmonization of the child's emotional state (3.38\%); development of cognitive interests $(2.02 \%)$; development of fine motor skills (2.02\%); harmonization of behavior $(2.02 \%)$ and speech development $(0.68 \%)$. Thus, most teachers point to the prosocial orientation of involving children with special educational needs in out-of-school education, with no indication of the importance of out-of-school education in the process of vocational socialization of such children.

Analyzing the answers of teachers to the question "What difficulties do you have working with children with special educational needs?" (among multiple choice answers 158 answers were received), it was found that $25.32 \%$ of respondents indicate the absence of problems in the education of children with special educational needs, while $24.68 \%$ of answers indicate behavioral disorders in children with special educational needs, which negatively affect the quality of out-of-school education. $19.63 \%$ of teachers' answers indicate a lack of knowledge of special methods of teaching children with special educational needs; $15.82 \%$ indicate a lack of cognitive interest in these children; $12.02 \%$ of answers indicate difficulties in establishing productive contact and interaction, and $2.53 \%$ of answers indicate insufficient funding and poor material and technical base of out-of-school education institutions.

Let us consider the results of expert evaluation. At this stage, the opinion of experts on the use of compensatory resources for out-of-school education in the process of involving school-age children with mental disabilities (primary school, adolescent, and senior school age) in various areas of out-of-school education were analyzed. Therefore, the experts' assessment was aimed at comparing the patterns of development of children with mental disabilities, their leading lines of development (at different ages), and compensatory opportunities of the environment created in different areas of out-of-school education, considering children's interests, potential and developmental needs. Note that in answering, each expert had the opportunity to choose several answer options. So to the question: "Do you think that it is most useful for children of primary school age with mental disabilities to attend classes in which areas of out-of-school education?" (artistic-aesthetic; artistic; tourist-local history; ecologicalnaturalistic; scientific-technical; researchexperimental; physical culture-sports or sports; military-patriotic; library-bibliographic; socialrehabilitation; health-improving; humanitarian) 201 answers were received. Most of the answers of experts indicate that primary school-age children should be involved in artistic and aesthetic $(25.86 \%)$ and physical culture and sports $(21.39 \%)$ areas of out-of-school education. Experts also point to the importance of involving children of primary school age with mental disabilities in the social rehabilitation direction of out-of-school education (17.91\%); artistic $16.92 \%$; ecological and naturalistic - $6.97 \%$; tourist and local lore $-4.48 \%$; wellness $-2.49 \%$; research and experimental $-1.98 \%$; scientific and technical - 1.48\%; humanitarian - $0.49 \%$. 


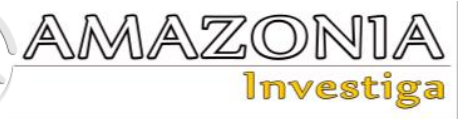

Simultaneously, all experts highlighted the inexediency of involving children with mental disabilities in military-patriotic and librarybibliographic areas of out-of-school education.

During the clarifying discussion, it was determined that the experts emphasize the importance of involving primary school children in the artistic and aesthetic direction of out-ofschool education. They point out that by mastering various techniques, pupils have an idea of sensory standards, develops spatial orientation; accuracy; tidiness, which are important factors in the success of schooling. According to experts, clubs and sections of physical culture and sports in out-of-school education will promote the development of physical qualities, stabilization of the emotional and volitional sphere. Experts note that the involvement of primary school children with mental disabilities in the social rehabilitation area will allow them to form an idea of themselves as members of society, develop communication skills and form an idea of socially approving behavior. Experts emphasize the positive impact of involving such children in art circles, in particular in theatrical art circles. The given tendency and the ability to "play" certain patterns of behavior in the theater circle make them learn the norms of socio-normative behavior.

During the teen years, experts emphasized the corrective orientation of the use of resources of artistic and aesthetic (19.7\%), physical culture and sports $(19.7 \%)$, and art $(17.24 \%)$ areas of out-of-school education. $10.35 \%$ of experts' answers indicate the importance of involving children in tourism and local lore; ecological and naturalistic $(9.37 \%)$, social rehabilitation (6.89\%); research and experimental $(5.42 \%)$; health $(3.94 \%)$; scientific and technical $(3.94 \%)$ and humanitarian $(3.45 \%)$ areas of out-of-school education. Experts rightly consider it inexpedient involving teenagers with mental disabilities in the library-bibliographic and military-patriotic areas of out-of-school education.

Simultaneously, during the clarifying conversation, most experts mentioned the importance of considering the interests and individual characteristics of children in determining the "targets" of corrective action and the direction of out-of-school education. For example, teenagers, which are characterized by pronounced affective excitability, emotional regulation disorders, insufficiently developed skills of social interaction. Adeniy, Omigbodun (2016) consider it appropriate attending clubs of physical culture, sports, and arts in out-of-school education. It will allow the sublimation of negative experiences into socially approving forms.

The involvement of teenagers in art and aesthetic circles allows them to form skills of manufacturing products (from clay, plasticine, fabric, etc.); involvement in ecological and naturalistic circles allows to consolidate the skills of caring for animals and plants. Involving children with mental disabilities in groups of these profiles helps children decide on their future profession.

In high school, experts emphasized the importance of involving children in artistic and aesthetic $15.73 \%$, physical culture, and sports (18.14\%), art (15.73\%), environmental, and naturalistic $(13.31 \%)$, tourism, and local lore (10.89\%) and social rehabilitation (7.26\%) areas of out-of-school education. Experts' answers indicated the expediency of involving children with special educational needs in research and experimental (6.04\%), health (4.44\%), humanitarian $(5.64 \%)$, scientific and technical $(2.82 \%)$ areas of out-of-school education. Experts consider it inexpedient involving children with mental disabilities in militarypatriotic and library-bibliographic areas of outof-school education.

It was studied to the opinion of experts to determine the impact of involving children with special educational needs in out-of-school education on their development. Thus, $28.41 \%$ of the answers of experts indicate that the involvement of children with special educational needs in out-of-school education will contribute to the harmonization of the process of child socialization; development of communication skills and social interaction skills (22.73\%); development of individual abilities and interests $(15.91 \%)$; promotion in general development $(10.23 \%)$. Some answers of experts indicate that the involvement of children in out-of-school education will contribute to the harmonization of the emotional state of the child, the development of the emotional and volitional sphere (4.55\%). $3.41 \%$ of experts' answers indicate an improvement in social adaptability; $3.41 \%$ for the harmonization of personal development; $3.41 \%$ for cognitive development; $3.41 \%$ on harmonization of behavior; $3.41 \%$ to improve self-realization and $1.12 \%$ of expert responses indicate the development of fine motor skills. Thus, comparing the results of the survey of teachers of out-of-school education institutions and experts, it was found that both categories of 
respondents agree that the involvement of children with special educational needs will contribute to their socialization. However, most experts emphasize the positive impact of out-ofschool education on the social, spiritual, moral development, self-realization of children with special educational needs. They see the importance of involving children with special educational needs as an important factor in successful professional self-realization. Instead, teachers of out-of-school education institutions point to the positive impact of involving children with special educational needs in out-of-school education as a factor in the development of communication skills and social interaction skills.

\section{Conclusions}

Ukraine is on the path of actively developing an open system of out-of-school education for children with special educational needs. Out-ofschool educational institutions involve children with musculoskeletal disorders, mental disabilities, autism spectrum disorders, mental retardation, severe speech disorders, hard of hearing, children with deafness, low vision, and children with blindness. It is determined that the leading model of involvement of children with special educational needs in out-of-school education institutions is collective educational integration, inclusive and individual education is less common. Children with special educational needs are involved in clubs (creative associations) of artistic and aesthetic, physical culture and sports, art, tourism and local lore, social rehabilitation, ecological and naturalistic, scientific and technical, health, humanitarian, research, and experimental and military-patriotic areas of out-of-school education. Children with mental disabilities of school-age rarely involved in artistic, aesthetic, and physical culture and sports areas of out-of-school education. Simultaneously, experts emphasize that when choosing the direction of out-of-school education, it is necessary to consider not only the interests and inclinations of children, individual and age characteristics of the child, compensatory opportunities of different areas of out-of-school education. The positive impact of involving children in out-of-school education, according to teachers and experts is manifested in the promotion of their socialization; social, spiritual, moral development; providing opportunities for the child for self-realization; development of communication and social skills; improving social adaptation and integration; preparation for life in society, the formation of life goals; correction of existing developmental disorders; creative development, etc.

\section{References}

Adeniy, Y., \& Omigbodun, O. (2016). The effect of a classroom-based intervention on the social skills of pupils with mental disability in Southwest Nigeria. Child and Adolescent Psychiatry and Mental Health, 10 (29). https://www.ncbi.nlm.nih.gov/pmc/articles/PM C5010731/

Bekh, I. D. (2018) Personality on the way to spiritual values: Kyiv-Chernivtsi: Bookrek.

Bykovska, O. V. (2016) Pedagogics of nonformal education as a subdiscipline of pedagogics. Native school, 11 - 12 (November December). http://nbuv.gov.ua/jpdf/rsh_2016_11-12_13.pdf

Fatih, H., \& Ganera, C. (2020) Recreation and physical activity of young girls with mental disability. Science, Movement and Health, XX, (2) Supplement, $237-241$. https://www.researchgate.net/publication/34445 1114_RECREATION_AND_PHYSICAL_ACT IVITY_OF_YOUNG_GIRLS_WITH_MENTA L_DISABILITY

Kamenez, N., Vaganova, O., Smirnova, Z., Kutepova, L., \& Vinokurova, I. (2019). The development of content of educational programs of additional education for professor-teaching composition in the organization of educational services of training with disability. Amazonia Investiga, $\quad 8(18), \quad$ 267-278. https://amazoniainvestiga.info/index.php/amazo nia/article/view/305/280

Khokhlina, O. (2019) Psychological content of a child's socialization in an educational institution. Individuality in the psychological dimensions of communities and professions in a networked society. Kyiv: Alfa-PIK, pp. 86-96. https://er.nau.edu.ua/handle/NAU/39525

Litovchenko, O. V. (2013) Social rehabilitation of children with special educational needs as one of the directions of social and pedagogical activity of out-of-school educational institutions. Practical psychology and social work, 1, pp. $53-57$.

Maksymenko, S., Kutsenko-Lada, G., \& Prorok, N. (2013) Psychological factors of selfdetermination of personality in the educational space: a collective monograph. Kirovograd: Imex-LTD.

Ministerio de Educación y Ciencia de Ucrania (2021) Education Forum-2021: Ministry of Education and Science is working to create a legal basis for the transformation of out-ofschool education. https://mon.gov.ua/ua/news/osvitnij-forum- 


\section{AMAZONDA \\ lvvestiga}

2021-mon-pracyuye-nad-stvorennyampravovogo-pidgruntya-dlya-transformaciyipozashkilnoyi-osviti

Nasyrova, E., \& Muller, O. (2019) Technologies of work with children with disabilities and disabled children in conditions of the network form of implementation of additional general development programs. Surgut: teaching aid.

Novosad, V., \& Seliverstov, R. G. (2009) Quantitative methods of expert evaluation: scientific method. Development. Kyiv: Research University.

Omelyanovich, I. (2015) Features of socialization of adolescent graduates with mental disabilities. Scientific Journal of the National Pedagogical University named after MP Drahomanov. Series 19: Correctional pedagogy and special psychology, 30, pp. $138-143$. http://enpuir.npu.edu.ua/handle/123456789/120 15

Pustovit, P. (2013) Out-of-school education and upbringing in Ukraine in the vectors of modern development. Education and pedagogical science, Vol. 3, pp. 5 - 10. http://www.irbisnbuv.gov.ua/cgi-

bin/irbis_nbuv/cgiirbis_64.exe?I21DBN=LINK $\&$ P21DBN=UJRN \&Z21ID $=\& S 21$ REF $=10 \& S 2$ $1 \mathrm{CNR}=20 \& \mathrm{~S} 21 \mathrm{STN}=1 \& \mathrm{~S} 21 \mathrm{FMT}=\mathrm{ASP} \_$meta $\&$ $\mathrm{C} 21 \mathrm{COM}=\mathrm{S} \& 2 \_\mathrm{S} 21 \mathrm{P} 03=\mathrm{FILA}=\& 2 \_\mathrm{S} 21 \mathrm{STR}=$ OsDon_2013_3_2

Suprun, M. O., Vysotska, A. V., \& Gladchenko, I. V. (2014) Socialization of a child with mental disabilities in the modern educational dimension. Kyiv: Institute of Special Pedagogy of the National Academy of Pedagogical Sciences of Ukraine.

Syniov, V.M. Bystrova, Yu.O. Kovalenko, V.Ye., \& Bystrov, A.Ye. (2019). The coverage of the problem of emotional and behavioral disorders in people with mental disabilities in the Ukrainian psychological and pedagogical science. Actual Problems of Correctional Education (Pedagogical Sciences), 13, 242-256. http://aqce.com.ua/download/publications/521/4 77.pdf/

Syniov, V.M. (2018) New school of Ukraine and problems of providing quality education for children with special needs. Social and life practice of children with mental disabilities in educational and rehabilitation centers: oriented manual. Dnipro: Innovation pp. $26-32$. https://dnmcps.com.ua/sites/default/files/201906/16/2/\%D0\%9F\%D0\%BE\%D1\%81\%D1\%96 \%D0\%B1\%D0\%BD\%D0\%B8\%D0\%BA.\%20 $\% \mathrm{D} 0 \% \mathrm{~A} 1 \% \mathrm{D} 0 \% \mathrm{BE} \% \mathrm{D} 1 \% 86 \% \mathrm{D} 1 \% 96 \% \mathrm{D} 0 \%$ B0\%D0\%BB\%D1\%8C\%D0\%BD\%D0\%B0\%2 0\%D1\%82\%D0\%B0\%20\%D0\%B6\%D0\%B8\% D1\%82\%D1\%82\%D1\%94\%D0\%B2\%D0\%B0 $\% 20 \% \mathrm{D} 0 \% \mathrm{BF} \% \mathrm{D} 1 \% 80 \% \mathrm{D} 0 \% \mathrm{~B} 0 \% \mathrm{D} 0 \% \mathrm{BA} \%$
D1\%82\%D0\%B8\%D0\%BA\%D0\%B0\%20\%D0 $\% \mathrm{~B} 4 \% \mathrm{D} 1 \% 96 \% \mathrm{D} 1 \% 82 \% \mathrm{D} 0 \% \mathrm{~B} 5 \% \mathrm{D} 0 \% \mathrm{~B} 9 \% 2$ 0\%D0\%B7\%20\%D1\%96\%D0\%BD\%D1\%82\% D0\%B5\%D0\%BB\%D0\%B5\%D0\%BA\%D1\%8 $2 \% \mathrm{D} 1 \% 83 \% \mathrm{D} 0 \% \mathrm{~B} 0 \% \mathrm{D} 0 \% \mathrm{BB} \% \mathrm{D} 1 \% 8 \mathrm{C} \% \mathrm{D} 0$ $\% \mathrm{BD} \% \mathrm{D} 0 \% \mathrm{~B} 8 \% \mathrm{D} 0 \% \mathrm{BC} \% \mathrm{D} 0 \% \mathrm{~B} 8 \% 20 \% \mathrm{D} 0 \%$ BF\%D0\%BE\%D1\%80\%D1\%83\%D1\%88\%D0 $\% \mathrm{~B} 5 \% \mathrm{D} 0 \% \mathrm{BD} \% \mathrm{D} 0 \% \mathrm{BD} \% \mathrm{D} 1 \% 8 \mathrm{~F} \% \mathrm{D} 0 \% \mathrm{BC}$ $\%$ D0\%B8\%20\%D0\%B2\%20\%D1\%83\%D0\%B C\%D0\%BE\%D0\%B2\%D0\%B0\%D1\%85\%20 $\%$ D0\%9D\%D0\%A0\%D0\%A6.pdf

Syniov, V.M., \& Kovalenko, V.Ye. (2021) The models of involving children with special educational needs in the educational process of out-of-school education institutions. The collection of scientific works on the materials of the regional scientific-practical seminar "Use of resources of out-of-school education during the socialization process of children with special educational needs." Edited by Yu. D. Boychuk. H.S. Skovoroda Kharkiv National Pedagogical University, $\quad$ pp. $\quad 164 \quad-\quad 168$. https://drive.google.com/file/d/1g1BdLBxJHtU gLDuBLaTByUZTMRz-gB_K/view

Tatyanchikova, I. V. (2016) The ways to ensure the socialization of children with intellectual disabilities at special school. Actual Problems of Correctional Education (Pedagogical Sciences), 7, http://aqce.com.ua/vypusk-7-t-1-t2/tatjanchikova-iv-shljahi-zabezpechennjasocializacii-ditej-z-vadami-intelektualnogorozvitku-v-specialnomu-navchalnomuzakladi.html

Trani, J-F. Fowler, P., Bakhshi, P., \& Kumar, P (2019) Assessment of progress in education for children and youth with disabilities in Afghanistan: A multilevel analysis of repeated cross-sectional surveys. PLoS ONE, 14(6), e0217677.

https://journals.plos.org/plosone/article?id=10.1 371/journal.pone.0217677

Shields, N., King, M., Corbett, M., \& Imms, K. (2013) Is participation among children with mental disabilities in outside school activities similar to their typically developing peers? A systematic review. Developmental Neurorehabilitation, $17(1)$,

https://pubmed.ncbi.nlm.nih.gov/24087974/

Shulzhenko, D. I. (2021) Out-of-school education as a psychological factor in creating a situation of success in children with autistic spectrum disorders. The collection of scientific works on the materials of the regional scientific-practical seminar "Use of resources of out-of-school education during the socialization process of children with special educational needs." Edited by Yu. D. Boychuk. H.S. Skovoroda Kharkiv National Pedagogical University, $\quad$ pp. $196 \quad-\quad 198$. https://drive.google.com/file/d/1g1BdLBxJHtUgL DuBLaTByUZTMRz-gB_K/view 
